\title{
An Explanation Of Financial Analysis Using The FASB's Preliminary Views On Financial Statement Presentation
}

Daniel Acton, St. John Fisher College, USA

\begin{abstract}
The Financial Accounting Standards Board (FASB) issued a discussion paper entitled "Preliminary Views on Financial Statement Presentation" on October 16, 2008, in which they presented a new format for the primary financial statements. The proposed statements are segmented into functional activities of the entity on a net-asset basis. The Board's objectives are to present a cohesive set of financial statements that are useful in predicting future cash flows and assessing liquidity and financial flexibility. This paper describes the proposed statements, examines the application of financial ratios, and assesses the extent to which the Board's objectives are satisfied.
\end{abstract}

Keywords: cash flows, solvency

\section{INTRODUCTION}

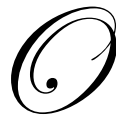

n October 16, 2008 the Financial Accounting Standards Board (FASB) issued a discussion paper entitled "Preliminary Views on Financial Statement Presentation." In this document, the Board presented a new format for the primary financial statements. The views are those of the FASB and the International Accounting Standards Board (IASB) and have been developed as part of their joint project on financial statement presentation. The Board is seeking responses on whether "...the presentation model proposed in this discussion paper would improve the usefulness of the information provided in an entity's financial statements and help users make decisions in their capacity as capital providers." Financial analysts use ratio analysis in their decision-making process. This paper investigates the impact of this proposed financial statement format on financial statement ratio analysis.

The proposed financial statement presentation was the result of the joint collaboration of the IASB and FASB, which was initiated by the 2002 Norwalk Agreement. Their joint work was divided into three phases. Phase A considered the statements that constitute a complete set of financial statements. Phase B considered financial statement presentation and Phase $\mathrm{C}$ addressed interim financial statement presentation. The discussion paper referred to in this paper was Phase B of the joint project. It applies to all entities except not-for-profit and nonpublic entities.

The Board developed three objectives of their proposed presentation model. These are:

1. To portray a cohesive financial picture of an entity's activities.

2. To disaggregate information so that it is useful in predicting an entity's future cash flows.

3. To help users assess an entity's liquidity and financial flexibility.

It is important to note that in Phase B, the Board was not addressing recognition and measurement principles. The Board focused on the fact that information currently is not presented consistently in financial statements and, in addition, information is not sufficiently disaggregated in those financial statements. 


\section{CLASSIFICATION IN THE NEW MODEL}

The Board's model requires an entity to present financial information about how it creates value (business activities) separately from financial information about the way it finances those activities (financing activities). The financial statements are separated into five sections: 1 . business activities that have operating and investing components, 2. financing activities, 3. income taxes, 4. discontinued operations, and 5. other comprehensive income/equity.

Classification must be consistent among all financial statements. In particular, the classification of line items in the statement of financial position determines the classification of those same items in the statements of comprehensive income and cash flows. The business section of the statement of financial position should include "assets and liabilities that management views as part of its continuing business activities." Business activities are defined as those "conducted with the intention of creating value, such as producing goods and providing services." Within the business section, operating assets and liabilities are those used for the central purpose of creating value in the primary business activity. Investing assets and liabilities are those management views as "unrelated to the central purpose for which the entity is in business." The financing assets-primarily cash, and liabilities are used by the business to finance the business and other activities.

\section{The Statement of Comprehensive Income}

The proposed format requires a single statement of comprehensive income with other comprehensive income (OCI) items presented on the face of the statement. The statement has separate sections for business activities (both operating and investing), financing activities, income taxes, discontinued operations and OCI. It should be noted that income tax expense is not allocated to the business and financing sections; instead, it is shown as a separate line item. Only discontinued operations and OCI are shown net of tax.

\section{The Statement of Financial Position}

The proposed statement has five separate sections: 1 . business, which includes operating and investing activities, 2. financing, 3. discontinued operations, 4. income taxes and 5. equity. Within the business and the financing sections, assets and liabilities are classified as short-term and long-term. In addition, a net-asset basis is used instead of the traditional GAAP balance sheet format. In the business section, total operating liabilities are subtracted from total operating assets to get net operating assets. Total investing assets then are combined with net operating assets to get net business assets.

Financing assets are comprised primarily of cash, and financing liabilities are classified as either short-term or long-term. The difference between total financing assets and total financing liabilities is reported as net financing liabilities.

Discontinued assets and related liabilities are classified as available for sale. In the income tax section, deferred taxes are classified as either assets or liabilities and as short- or long-term. The net asset or liability balance is combined with the net asset or net liability balance of the prior three sections to get net assets. The fifth section is equity and it shows the composition of equity; it also serves as a proof or balancing amount for total net assets.

\section{The Statement of Cash Flows}

This statement follows the current GAAP terminology in that three sections are presented: 1 . operating, 2 . investing, and 3. financing. These three sections are not equivalent however, to the three sections of the cash flow statement under GAAP. The proposal requires the direct method of presenting the cash from operations. In addition, the notes would include a reconciliation of cash flows to comprehensive income. 


\section{FINANCIAL STATEMENT ANALYSIS}

\section{Profitability Ratios}

This paper looks at basic financial statement analysis using the FASB's proposed format and considers these in the broad context of profitability and solvency. Traditional return on equity (ROE) is computed as net profit divided by total stockholders' equity. Under the proposed format, profit is disaggregated into total operating income, total investing income, and total financing expense. The Board does not require allocation of tax expense/benefit to each of these categories; therefore, a meaningful ratio of ROE cannot be made for these subcomponents.

It should be noted that comprehensive income (OCI) must be on the face of the proposed income statement which may influence analysts to reconsider whether to include or exclude it in the computation of ROE. Usually OCI is excluded from income when computing ROE. In contrast, accumulated other comprehensive income (AOCI) is included in total stockholders' equity when computing ROE. To be consistent, OCI should be treated the same in both income and stockholders' equity.

Using the proposed format, ROE can be modified to provide detailed information for analysts. ROE is normally subdivided into margin (net income/net sales), asset turnover (net sales/average total assets), and leverage (average total assets/average stockholders' equity). Margin can be divided into the following three components:

1. (Net income/profit from continuing operations before tax-PCOBT)

2. (PCOBT/total operating income-TOI)

3. (TOI/net sales).

The first expression (net income/PCOBT) indicates the percentage of income from continuing operations, before tax, that was converted into net income or, conversely, the effective income tax rate. The second expression (PCOBT/TOI) indicates the percentage of TOI that is converted into PCOBT or, conversely, the impact of financing and investing activities on PCOBT. The third expression (TOI/sales) indicates the percentage of each sales dollar that becomes TOI. The computation of asset turnover and leverage is unaffected by the proposed format. Margin is the same for both formats, although the components of margin are different. ROE is the same under both approaches.

\section{Risk Ratios}

Computation of the current ratio requires combining the short-term assets and liabilities in each section of the proposed statement of financial position. The proposed format for the statement of financial position includes business and the two subcomponents, operating activities and investing activities, financing, as well as discontinued operations, income tax, and equity. Within these sections, the line items are classified as short-term or long-term. The current ratio can be computed easily by combining the current items in each section of the statement, but this raises the question as to the benefit obtained by the proposed format in assessing short-term solvency. The ratio of current assets to current liabilities in the business operating activities section of the statement can be computed, but because it excludes such items as short-term investments and short-term debt, it is an incomplete measure of the short-term solvency for the company taken as a whole.

The ratio of operating cash flows to current liabilities varies extremely between the current GAAP statements and the proposed format. This variation is due to the fact that operating cash flows under the proposed format include the effects of operating asset transactions and exclude the effects of interest paid and received, dividends paid and received, and taxes paid. This presentation differs from both current IFRS and GAAP. This raises the question as to which is more useful in measuring solvency and assessing future cash flows. Other solvency ratios, such as turnover, days outstanding, and debt-equity ratios, are unaffected by the proposed format. 


\section{CONCLUSION}

The FASB established three objectives for the proposed financial statements. The first objective is to present a cohesive set of financial statements. The statements follow the same classification system which satisfies this objective. For example, the statement of comprehensive income presents income from business operations. The statement of financial position presents assets and liabilities for business operations, and the statement of cash flows presents the change in cash due to business operations. A shortcoming is that income taxes are not allocated to any classification of the statements which results in an incomplete picture of the results from business operations.

The FASB's second objective is to disaggregate information so that it is useful in predicting future cash flows. Empirical testing will be needed to determine if disaggregated statements are better at predicting future cash flows.

The third objective is to help users assess financial liquidity and flexibility. Computation of the current ratio can be computed for operations, but it excludes significant assets and liabilities in investments and financing sections that are essential to measure the overall liquidity. In that the liabilities are obligations of the entire entity and not of each section, it is doubtful that liquidity is more evident under the proposed format. Operating cash flows are significantly different using the proposed format. The resulting ratio may be less predictive of future cash flows in that it includes the effects of investing activities which vary more than cash from operations. Financial flexibility can be defined as the ability of an entity to take effective actions to alter amounts and timing of cash flows so that it can respond to unexpected needs and opportunities. The proposed format offers no apparent advantage in assessing financial flexibility.

\section{AUTHOR INFORMATION}

Daniel Acton is Associate Professor of Accounting at St. John Fisher College in Rochester, New York. He is a CPA and earned his doctorate in accounting at Kent State University. His research and publications are in the area of financial reporting.

\section{REFERENCES}

1. Discussion Paper: Preliminary Views on Financial Statement Presentation. Norwalk, CT: Financial Accounting Standards Board, October, 2008.

2. B Byoun, Soku. "Financial Flexibility, Leverage, and Firm Size," Waco, TX. January 2007.

3. Stickney, Clyde P., Paul R. Brown, James M. Whalen. Financial Reporting, Financial Statement Analysis, and Valuation._ $6^{\text {th }}$ ed. Mason, $\mathrm{OH}$ : Thompson Higher Education, 2007. 